4. Aryeshkina, S.N. (2010) Kvalifikaciya rozkradannya narkoty'chny'x zasobiv, psy'xotropny'x rechovy'n, yix analogiv ta prekursoriv [Qualification of theft of narcotic drugs, psychotropic substances, their analogues and precursors] [avtoref. dy's. kand. yury'd. nauk]. K. (in Ukrainian)

5. Okushko, A. V. (2017). Harakterystyka sposobiv rozkradannja narkotykiv u medychnyh zakladah [Characteristics of methods of drug theft in medical institutions]. U Osnovni naprjamy ta problemy protydii' narkomanii' [The main directions and problems of drug addiction] (s. 47-49). Nac. akad. vnutr. sprav (in Ukrainian).
6. Stupny'k, Ya.V. \& Koshtura, A.V. Anty'narkoty'chne zakonodavstvo v vitli transformaciyi polity'ky' proty'diyi narkozlochy'nnosti [Anti-drug legislation in the light of the transformation of the policy to combat drug crime]. Naukovy'j visny'k Uzhgorods'kogo nacional'nogo universy'tetu. Seriya Prava [Scientific Bulletin of Uzhhorod National University. Law Series], (31), 70-74 (in Ukrainian).

R. Grinyuk, Dr of Law, Prof.

Vasyl Stus Donetsk National University, Vinnytsia, Ukraine,

B. Kindyuk, Dr of Law, Prof.

Odessa State University of Internal Affairs, Odessa, Ukraine

\title{
MEDICAL WORKERS' LIABILITY FOR CRIMES IN THE FIELD OF TRAFFICKING OF NARCOTIC PRODUCTS UNDER ARTICLE 320 OF THE CRIMINAL CODE OF UKRAINE
}

The article considers the peculiarities of criminal liability of employees of health care institutions for violation of the provisions of Art. 320 of the Criminal Code of Ukraine, which consists of two parts, which differ in the ways (forms) of committing criminal offenses and limits of liability. The methodological basis of the study includes logical-semantic method, by which the types of methods (forms) of committing criminal offenses under Art. 320 of the Criminal Code of Ukraine are studied; a systematic approach, on the basis of which the author analyses the sequence of actions of employees of investigative bodies in the investigation of crimes on the grounds of criminal activity provided for in the provisions of this article. It is established that Art. 320 of the Criminal Code of Ukraine consists of two parts and provides for a wide range of criminal offenses, in particular the cultivation of sleeping poppy or hemp; violation of the rules of production, manufacture, storage, accounting, release, distribution, trade, transportation, shipment or use of narcotic drugs, psychotropic substances, their analogues or precursors intended for the production or manufacture of these drugs or substances; theft, misappropriation, extortion of narcotic drugs, psychotropic substances, their analogues or precursors, or their acquisition by fraud or abuse of office by an official, etc. It is shown that the disposition of Art. 320 of the Criminal Code of Ukraine has a blanket nature, which requires specification of its provisions in other regulations, including orders, instructions, rules. It is emphasized that employees of medical institutions and health care institutions must clearly know the content of the resolution of the Cabinet of Ministers No 770 "On approval of the list of narcotic drugs, psychotropic substances and precursors" from 06.06.2000, the order of the Ministry of Health № 188 "On approval of tables of small, large and especially large amounts of narcotic drugs, psychotropic substances and precursors that are in illicit traffic" from 01.08.2000, which will significantly help them to avoid offenses related to drug trafficking. Special attention should by paid to compliance with the rules of storage, transfer, accounting, release, distribution, trade, transportation, as well as the introduction of drug logs. The article also shows the sequence of actions of employees of investigative bodies during crime investigation on grounds of the criminal activity provided by Art. 320 of the Criminal Code of Ukraine.

Keywords: drugs, psychotropic substances, precursors, Criminal Code of Ukraine, crime, medical workers, procedure for investigative actions.

Bulletin of Taras Shevchenko National University of Kyiv.

Legal Studies, 2021; 1 (116): 19-23

удК: 343.222.4:343.575(616-051)(477)

DOI: https:doi.org/10.17721/1728-2195/2021/1.116-4
ISSN 1728-2195

(C) Taras Shevchenko National University of Kyiv, Publishing center "Kyiv University", 2020

О. Котюк, канд. юрид. наук, асист. ORCID ID: 0000-0002-6464-2315

Київський національний університет імені Тараса Шевченка, Київ, Україна

\section{ПРАВОМІРНІСТЬ ЯК СВІТОГЛЯДНИЙ КРИТЕРІЙ ОЦІНКИ ПОВЕДІНКИ ТА ДІЯЛЬНОСТІ}

Проаналізовано суперечності в наявних концептуальних підходах до визначення категорії "правомірність" та обґрунтування власної концепції ії змісту.

Методологією цього дослідження є аналіз генези уявлень про поняття "правомірність", його сутнісних характеристик і засобів практичного забезпечення правомірної поведінки й діяльності. Автор привертає увагу до того, що оскільки спочатку поняття "правомірність" тлумачилась виключно з позицій позитивістського праворозуміння, то на підставі цього робився висновок, що головним критерієм правомірної поведінки й діяльності є ї̈ відповідність вимогам закону. Згодом складовою вимог правомірності стали визнавати й основні принципи права. A натепер усе більшої підтримки набуває концепція, згідно з якою правомірною є поведінка, яка відповідає вимогам не лише нормам позитивного права, а й вимогам інших загальновизнаних соціальних норм, які відображають найвищі соціальні цінності. Саме тому основними вимогами правомірності є верховенство права, тобто пріоритет прав $і$ свобод людини в усіх сферах суспільного життя; їхня гарантованість; обов'язковість їх дотримання всіма учасниками правовідносин; ефективна та послідовна боротьба з посяганнями на них; невідворотність відповідальності за правопорушення.

3 урахуванням вимог засади верховенства права та природно-правового праворозуміння автором запропоновано власну концепцію змісту категорії "правомірність" і привернено увагу до суперечливих положень Конституції України, які стають очевидними у процесі істинного розуміння цієї категорії. Крім того, автор обґрунтовує, що умовами забезпечення правопорядку, засади верховенства права, а відтак, і правомірності поведінки і діяльності, є відповідні гарантії, тобто умови, засоби й заходи, за допомогою яких вона забезпечується, зокрема: економічні, ідеологічні, політичні, юридичні, громадські та міжнародні. Що ж до практичних способів їі забезпечення, то ними є: переконання, заохочення, заходи примусу та профілактична діяльність.

Ключові слова: верховенство права, правопорядок, правомірність, законність, принципи права, соціальні норми, поведінка, діяльність.

ВСтуп. Як відомо, засада законності є вимогою суворого та неухильного дотримання законів усіма органами, організаціями, посадовими особами та громадянами. За таких умов головним критерієм оцінки й поведінки, і діяльності була ії відповідність вимогам закону, а поняття "правомірність" практично не викори- стовувалось. Однак оскільки зміна світоглядних орієнтирів у політико-правовій організації суспільного життя зумовила їхню демократизацію, проголошення людини найвищою соціальною цінністю та визнання засади верховенства права, то це змусило привернути увагу й до цього поняття як з теоретичного, так і з практичного 
погляду. Як наслідок, із приводу цієї проблеми почали з'являтися окремі статті та дослідження на монографічному рівні, прикладом яких є дисертації О.І. Котюка (2013) [1] і Г. В. Свириденко (2018) [2]. Однак в умовах панування позитивістського праворозуміння вважалося, що хоча поняття "правомірність" є багатозначним, зазвичай під ним розуміють те, "що має певне значення 3 погляду реалізації чинного в суспільстві права, вираженого у нормах законодавства" [3, с. 1101].

3 урахуванням цього метою цієї сmammi $є$ аналіз наявних концептуальних підходів до визначення категорії "правомірність", обґрунтування власної його концепції та уточнення характеристики системи засобів забезпечення правомірної поведінки й діяльності.

\section{ВИКЛАД ОСНОВНОГО МАТЕРІАЛУ.}

Традиційні підходи до розуміння поняття "правомірність"

Традиційно вважається, що оскільки поняття "правомірність" означає: узгодженість поведінки з вимогами правових норм; неприпустимість протиставлення поведінки їхнім вимогам; рекомендовано, дозволено і $€$ обов'язковим лише те, що передбачене законом, то "правомірна поведінка" тлумачиться як суспільно корисна, необхідна, бажана й допустима система діянь, яка "відповідає правовим нормам і гарантується державою" [4, с. 448]; "відповідає приписам норм усіх галузей права" [5, с. 25] тощо.

Що ж до змісту цього поняття, то складовими правомірності визнають: 1) її суб'єкта; 2) суб'єктивну сторону, змістом якої $€$ позитивна мотивація до вчинення конкретних дій і переконаність суб'єкта в необхідності діяти саме так; 3) об'єкт, що є матеріальним і духовним благом, із приводу яких вчиняються конкретні дії; 4) об'єктивна сторона, тобто фактичний прояв конкретних дій і їхні наслідки.

На підставі наведених підходів робиться й висновок, що "з приводу того, що правомірна поведінка повинна відповідати або узгоджуватися з приписами правових норм, мабуть, не повинно виникати жодних заперечень" [2, c. 20].

Водночас, як зазначає С. Погребняк, в умовах лібералізації й демократизації суспільного життя та визнання прав і свобод людини найвищою соціальною цінністю, дослідження правомірної поведінки не може відбуватися лише за допомогою формально-логічних прийомів наукового пізнання, оскільки абсолютизація такого підходу необґрунтовано звужує ссреру правового регулювання суспільних відносин лише необхідністю реалізації норм позитивного права, виносячи за дужки регулятивний потенціал принципів права, у яких відображаються найвищі соціальні цінності, як, наприклад, справедливість, гуманізм, свобода, рівність тощо [6, с. 240].

Привертається увага й до того, що з позицій історичного підходу правомірна поведінка ґрунтується на сформованих у певних темпорально-просторових виміpax звичаях, традиціях, етичних правилах тощо, які сприймаються більшістю громадян [7, с. 183]; що "ототожнення правового впливу з незабороненістю призводить до приписування праву невластивої йому ролі "глобального" регулятора суспільних відносин, до непомірного перебільшення правової регламентації та державного контролю за поведінкою громадян, а відтак - і невиправданого звуження сфери особистої свободи" [8, с. 155]. Тобто традиційні підходи до розуміння правомірної поведінки $€$ ознаками й наслідками тоталітарних політичних режимів і вибудуваних ними критеріїв оцінки соціальних цінностей.
Демократичні критерії визначення поняття "правомірність"

Що ж до демократичних критеріїв оцінки поведінки, то тут варто виходити з того, що не може бути підставою для виправдання аморального вчинку лише те, що він не заборонений законом [9, с. 31]. Тим більше не може бути виправданням діяльності, яка здійснюється згідно з вимогами закону, який є аморальним, лише те, що цей закон неправовим ще офріційно не визнаний.

А з урахуванням цих настанов стає очевидним, що правомірна поведінка - це не лише та, що не порушує лише правових норм, а та, що узгоджується й із принципами права, "духом законів", джерелами яких $€$ норми моралі, звичаї й інші загальновизнані соціальні норми, які $€$ втіленням абсолютних, загальнолюдських цінностей, через що вони є загальносоціальними, а відтак, і найвищими критеріями її оцінки.

Заслуговує на увагу й висновок, що в широкому розумінні поведінка людини є, по суті, метанормативною, тобто вона, зазвичай, підпадає під регламентацію не однієї, а декількох груп соціальних норм, які завжди об'єктивно фрункціонують у кожному суспільстві. Саме тому варто визнати доцільним виокремлення так званої загальної нормативної поведінки, тобто такої, яка регулюється багатьма соціальними нормами - моральними, релігійними, правовими, звичаєвими тощо [10, с. 35]. Прогресивними, а тому й актуальними є висновки, що правомірна поведінка "узгоджується з усіма вимогами норм буттєвого, соціоприродного, природно-правового простору та позитивно-правового поля" [11, с. 92]; що нині реалістичними стають наукові роздуми про те, що юриспруденція повинна ставати наукою про соціальну поведінку людини у правовій ссрері [12, с. 1385-1387].

А з урахуванням цього стає зрозумілим й висновок О. Шпенглера, що "право завжди звернене до людей, які, окрім статутів, внутрішньо розуміють те, про що немає сенсу говорити, розуміють саме з огляду на це й чудово собі уявляють, як ним користуватися. Будь-яке право $є$ переважно звичаєвим: нехай собі закон визначає слова - а розтлумачуватиме їх життя" [13, с. 85]. Та й не випадково кажуть, що в найбільш загальному, широкому розумінні правомірною $є$ та поведінка, яка визнана на певних соціальних рівнях правильною або/та праведною, справедливою, такою, що пов'язана із сакральними елементами буття. Тобто правомірною, а відтак - справедливою поведінкою $є$ та, що узгоджується з волею Бога, із Божим законом.

Однак, оскільки справедливість є морально-етичною категорією, то об'єктивним критерієм оцінки поведінки й діяльності вона бути не може. Адже навіть "золоте правило" - стався до людей так, як би ти хотів, щоб вони ставилися до тебе", $є$ надто суб'єктивним. 3 урахуванням цього й стає очевидним, що об'єктивним критерієм поведінки й діяльності може бути не закон, і не справедливість, а її відповідність правам і свободам людини, які закріплені в загальновизнаних соціальних нормах.

Мотиваційні засади правомірної поведінки

що ж до мотиваційної основи і права, і правомірної поведінки, то нею $є$ матеріальні та духовні цінності. А тому коли фактична правова дійсність із різних причин втрачає цю ціннісну основу, то право починає втрачати свій справжній регулятивний потенціал, а правомірна поведінка - сутнісні внутрішні характеристики, унаслідок чого її зміст стає занадто формалізованим і позбавленим повноти телеологічного смислу [14, с. 106-120].

Важливим $є$ й те, що між правилами, встановленими державою і морально-етичними нормами, крім інших, $€$ відмінності у спонукальних механізмах діяти згідно з їхніми приписами. Зокрема, якщо закон зобов'язує викону- 
вати його приписи незалежно від наявності осмислення та логічного обґрунтування такого виконання, і примушують до цього лише погрозою можливих санкцій, то до виконання приписів моралі спонукає наявність осмисленого й логічного обґрунтування такої необхідності усвідомленням морально-етичного принципу справедливості та можливості як суспільного, так і власного осуду.

От тому правомірну поведінку не варто розглядати не лише поза контекстом тих процесів, які відбуваються у суспільстві та державі, а й поза контекстом свідомості людини як суб'єкта суспільних, а отже, правових відносин. Водночас, як переконливо свідчать складні та суперечливі реалії сьогодення, одна з основних проблем формування належного рівня соціально активної правомірної поведінки перебуває не стільки у формальноюридичній площині (наприклад, якість законів, ефективний апарат держави тощо), скільки в самій людині, її свідомості та ціннісних орієнтаціях, прагненнях, інтересах тощо. У зв'язку з цим надзвичайно важливою складовою забезпечення соціально активної правомірної поведінки людини є фрормування морально-правової, ціннісної системи координат як суспільної та індивідуальної свідомості в цілому, так і правосвідомості, зокрема.

Отже, правомірна поведінка спочатку тлумачилась виключно з позицій позитивістського праворозуміння, внаслідок чого головним ії̈ критерієм визнавалась узгодженість лише із приписами правових норм. Згодом складовою її вимог почали визнавати й основоположні принципи права. А натепер усе більшої підтримки набуває концепція, згідно з якою правомірною є поведінка, яка відповідає вимогам не лише нормам позитивного права, а й вимогам інших загальновизнаних соціальних норм (названих Конституційним Судом "соціальними регуляторами"), які відображають найвищі соціальні цінності.

Водночас, віддаючи належне прогресивним тенденціям, які простежуються у вказаних підходах, усе ж варто визнати, що вони продовжують базуватися на позитивістському праворозумінні у якому поняття "право" ототожнюється із законом, а його форма - із його змістом. Що ж до істинного розуміння категорії "правомірність", то у ході його визначення необхідно виходити з того, що конституційне визнання Україною людини, її прав і свобод найвищою соціальною цінністю та засади верховенства права $є$ юридичною підставою для висновку про фрактичну трансформацію її правової системи із традиційного позитивістського праворозуміння в природно-правове, згідно з яким правом визнаються не правила, встановлені державою у формі закону, а права і свободи людини, змістом яких $€$ її повноваження на володіння, користування й розпорядження соціальними цінностями. А 3 урахуванням цього стає очевидним, що поняття "правомірність" означає відповідність вимогам, що випливають із прав і свобод суб'єктів суспільних відносин, незалежно від того якими із загальновизнаних соціальних норм ці права і свободи визнані. А оскільки соціальні норми поведінці завжди передують, то саме цим і створюються передумови для належної її оцінки на предмет відповідності їхнім вимогам. Як наслідок, за таких обставин засада законності стає складовою засади правомірності, але лише за тих умов, що закон $є$ правовим.

Що ж до діяльності, то оскільки за змістом вона $є$ діями, спрямованими на досягнення конкретної мети і стосується насамперед державних органів і посадових осіб, то з урахуванням викладеного стає очевидним, що вимоги Конституції України згідно з якими: 1) "державні органи і посадові особи зобов'язані діяти лише на підставі, в межах повноважень та у спосіб, що передбачені Конституцією та законами України" (ст. 6 та ст. 19);
2) "виключно законами України визначаються: права і свободи людини і громадянина, гарантії цих прав і свобод; основні обов'язки громадянина" (п. 1 ст. 92), а також "діяння, які $€$ злочинами, адміністративними або дисциплінарними правопорушеннями, та відповідальність за них" (п. 22 ст. 92) [15], також є відображенням суто позитивістського праворозуміння, а тому суперечать і передбаченій у ст. 8 тієї ж Конституції засаді верховенства права, і вимогам ії ст. 22 згідно з якими "права і свободи людини і громадянина, закріплені цією Конституцією, не $є$ вичерпними", і фактичним вимогам їхньої правомірності.

Отже, оскільки суспільний порядок базується на верховенстві та гарантованості прав і свобод людини, то основним критерієм поведінки й діяльності повинна бути засада їхньої правомірності, яка $є$ однією з засад суспільного і державного життя, що полягає у вимозі суворого та неухильного підтримання правопорядку й дотримання прав і свобод людини, незалежно від того, якими із загальновизнаних соиіальних норм вони визнані, усіма учасниками суспільних відносин. Основними її вимогами є: верховенство права, тобто пріоритет прав і свобод людини в усіх сфрерах суспільного життя; їхня гарантованість; обов'язковість їх дотримання усіма учасниками правовідносин; ефективна та послідовна боротьба з посяганнями на них; невідворотність відповідальності за правопорушення.

Механізми забезпечення правомірної поведінки

Що ж до умов забезпечення правопорядку, верховенства права, а відтак, і правомірності поведінки й діяльності, то ними є відповідні гарантії, тобто умови, засоби і заходи, за допомогою яких вони забезпечуються, зокрема: економічні, ідеологічні, політичні, юридичні, громадські та міжнародні.

Економічні гарантії - це рівень розвитку економічної системи суспільства, що визначає рівень добробуту, а отже, й зацікавленість або незацікавленість його членів у підтриманні існуючого правопорядку та прав і свобод людини, i $€$ об'єктивною передумовою правомірності поведінки й діяльності.

Ідеологічні гарантії є системою поглядів і ціннісних орієнтирів і критеріїв поведінки, що склалися у суспільстві й визначають рівень правосвідомості як суспільства в цілому, так і кожного його члена зокрема та їхнє ставлення до існуючого правопорядку. Як наслідок, правопорядок може визнаватися ними як соціальна цінність, а може й не визнаватися.

Політичні гарантії - це здійснення державної влади з урахуванням волевиявлення суспільства, що сприяє й справедливому врегулюванню суспільних відносин.

Юридичні гарантії - це наявність самих правових норм, які справедливо врегульовують суспільні відносини і користуються авторитетом у суспільстві, та наявність тих державно-правових інститутів, діяльністю яких забезпечується підтримання існуючого правопорядку. Практичними юридичними механізмами, завдяки яким забезпечується правопорядок, засада верховенства права та правомірність поведінки і діяльності, є: 1) досконалість правової системи, яка відповідає рівню розвитку суспільних відносин і забезпечує: втілення у правових нормах волевиявлення суспільства, що сприяє забезпеченню авторитету цих норм і готовності членів суспільства дотримуватись визначених ними правил; іï відповідність поняттям про загальнолюдські цінності, закріпленим у міжнародно-правових актах; повноту та внутрішню узгодженість нормативного регулювання суспільних відносин; відповідність вимогам технікоюридичного характеру; 2) ефективність роботи правотворчих органів, що забезпечує своєчасне врегулювання 
суспільних відносин, удосконалення законодавства та приведення його у відповідність до вимог суспільних відносин, які постійно розвиваються; 3) ефективна діяльність правоохоронних органів, яка сприяє підтриманню правопорядку і включає: конституційний суд як гарантію додержання конституційної законності; систему правосуддя як найвищу гарантію забезпечення прав i свобод людини; здійснення належного нагляду за підтриманням правопорядку; ефективне розкриття та розслідування правопорушень; профрілактична діяльність спрямована на запобігання їхньому вчиненню; 4) дієвість заходів примусового впливу.

Громадські гарантії - це заходи, що застосовуються громадськістю для підтримання правопорядку. У широкому розумінні - це діяльність будь-яких громадських організацій, які сприяють формуванню суспільної свідомості, а отже, і правосвідомості особи. А у вузькому діяльність громадських організацій, які спеціально створюються для підтримання правопорядку.

Міжнародні гарантії правопорядку - це діяльність міжнародних організацій, спеціалізованих органів та уповноважених осіб, спрямована на: визначення міжнародних стандартів у сфері правопорядку і, насамперед, у сфрері прав і свобод людини; здійснення контролю за їхнім дотриманням у різних країнах, яка може виявлятись у наданні офіційного права громадянам звертатися у міжнародні організації за захистом своїх прав, інспекційних поїздок представників цих організацій у регіони, де порушуються права людини, інституту міжнародних спостерігачів за проведенням виборів та інші; політичні та економічні заохочення дотримання загальновизнаних прав і свобод людини; застосування політичних, економічних і воєнних санкцій щодо держав - порушниць прав і свобод.

Що ж до практичних способів забезпечення засади верховенства права, правопорядку та правомірності поведінки й діяльності, то ними є: переконання активний, систематичний вплив на свідомість і поведінку суб'єктів правовідносин із метою виховання в них потреби, звички додержуватись правопорядку та загальновизнаних прав і свобод; заохочення - заходи морального, матеріального й організаційного характеру, що їх застосовують до суб'єктів суспільних відносин; примус - вольовий вплив на свідомість і поведінку 3 метою спонукання до додержання правопорядку; профолактична діяльність - це заходи, спрямовані на запобігання правопорушенням, усунення причин, що їх зумовлюють та умов, які їм сприяють.

ВИСнОВкИ. 1. Оскільки суспільний порядок базується на засаді верховенства права, яка передбачає пріоритет і гарантованість прав і свобод людини, то основним критерієм поведінки й діяльності повинна бути засада їхньої правомірності, яка є однією із засад суспільного й державного життя, що полягає у вимозі суворого і неухильного підтримання правопорядку та дотримання прав і свобод людини незалежно від того, якими із загальновизнаних соціальних норм вони визнані, усіма учасниками суспільних відносин.

2. Основними вимогами правомірності є: пріоритет і гарантованість прав і свобод людини в усіх сфрерах суспільного життя; обов'язковість їх дотримання усіма учасниками правовідносин; ефективна та послідовна боротьба з посяганнями на них; невідворотність відповідальності за правопорушення.

3. За таких обставин засада законності є складовою засади правомірності, але за умови, що закон $є$ правовим.

4. Умовами забезпечення правопорядку, засади верховенства права, а відтак, і правомірності поведінки й діяльності, $€$ відповідні гарантії, тобто умови, засоби та заходи, за допомогою яких вона забезпечується, зокрема: економічні, ідеологічні, політичні, юридичні, громадські та міжнародні.

5. Практичними способами забезпечення правомірності поведінки й діяльності є: переконання, заохочення, заходи примусу та профрілактична діяльність.

Список використаної літератури

1. Котюк О. І. Правомірність слідчих дій: умови визначення та засоби забезпечення : дис. ... канд. юрид. наук: спец. 12.00.01 / О. І. Котюк. - К. : Київ. нац. ун-т імені Тараса Шевченка, 2013.

2. Свириденко Г. В. Правомірна поведінка: сучасний контекст: монографія / Г. В. Свириденко. - К. : Вид-во "Юрид. думка", 2018.

3. Великий тлумачний словник української мови / Уклад. і гол. ред. В. Г. Бусел. - К. ; Ірпінь : Перун, 2005. - С. 1101.

4. Дробязко С. Г. Общая теория права : учеб. пособие / С. Г. Дробязко, В. С. Козлов. - Минск : Амалфея, 2005.

5. Пелевина М. С. Правомерное поведение - основа современного правового государства / М. С. Пелевина // Юрид. мысль. - 2014. № 6 (86). - С. 25-28.

6. Погребняк С. П. Основоположні принципи права (змістовна характеристика) : монографія / С. П. Погребняк. - Х. : Право, 2008.

7. Черданцев А. Ф. Толкование права и договора : учеб. пособие / А. Ф. Черданцев. - М. : ЮНИТИ-ДАНА, 2003.

8. Методологические $и$ теоретические проблемы государства и права развитого социализма / О. Э. Лейст и др. ; под ред. А. И. Денисова, О. Е. Кутафина. - М. : Изд-во Моск. ун-та, 1983.

9. Казаков В. Н. Правосознание и правомерное поведение : монографрія / В. Н. Казаков, В. П. Малахов. - М. : Мос. ун-т МВД РФ им. В. Я. Кикотя, 2002.

10. Рабінович П. М. Формування основ правового світогляду, правової свідомості та правової культури шкільної молоді (теоретико- й соціально-правове дослідження) / Праці Львівської лабораторії прав людини і громадянина НДІ держ. будівництва та місц. самовр. НАПрН України / П. М. Рабінович, Т. В. Бачинський. Серія 1. - Л. : Вид-во ЛОБФ "Медицина і право", 2015. - Вип. 29. - С. 35-46.

11. Романова А. Правомірна поведінка як умова самоствердження людини / А. Романова // Юрид. вісник. - 2014. - № 6. - С. 91-95.

12. Головатий С. Верховенство права : у 3 кн. / С. Головатий. - К. : Фенікс, 2006. - Кн. 3.

13. Шпенглер О. Закат Европы. Очерки морфологии мировой истории / О. Шпенглер; пер. с нем. И. Маханькова. - М. : Мысль, 1998. - Т. 2.

14. Гусарєв С. Д. Юридична діяльність: методологічні та теоретичні аспекти / С. Д. Гусарєв. - К. : Знання, 2005. - С. 106-120.

15. Конституція України [Електронний ресурс]. - Режим доступу : http://zakon0.rada.gov.ua/laws/show / 254к-вр

\section{References}

1. Kotiuk, O.I. (2013) Pravomirnist slidchykh dii: umovy vyznachennia ta zasoby zabezpechennia [Legality of investigative actions: conditions of definition and means of maintenance] [dys. kand. yuryd. nauk]. Kyiv. nats. un-t imeni Tarasa Shevchenka (in Ukrainian).

2. Svyrydenko, H.V. (2018) Pravomirna povedinka: suchasnyi kontekst [Legitimate behavior: modern context]. Kyiv: "Yurydychna dumka" (in Ukrainian)

3. Velykyi tlumachnyi slovnyk ukrainskoi movy [Large explanatory dictionary of the Ukrainian language] (2005), Ed. V.H. Busel. Kyiv, Irpin: Perun (in Ukrainian).

4. Drobjazko, S.G. \& Kozlov, V.S. (2005) Obshhaja teorija prava [General theory of law]. Minsk: Amalfeja (in Russian).

5. Pelevina, M.S. (2014) Pravomernoe povedenie - osnova sovremennogo pravovogo gosudarstva [Legitimate behavior is the basis of the modern rule of law]. Juridicheskaja mysl' [Legal thought]. (6 (86), 25-28 (in Russian).

6. Pohrebniak, S.P. (2008) Osnovopolozhni pryntsypy prava (zmistovna kharakterystyka) [Fundamental principles of law (substantive characteristics)]. Kharkiv: Pravo (in Ukrainian).

7. Cherdancev, A. F. (2003) Tolkovanie prava i dogovora [Interpretation of law and contract]. Moskva: JuNITI-DANA (in Russian).

8. O.Je. Lejst, M.N. Marchenko, A.I. Denisov, A.A. Kenenov i dr. (1983) Metodologicheskie i teoreticheskie problemy gosudarstva i prava razvitogo socializma [Methodological and theoretical problems of the state and the law of developed socialism]. Eds. A.I. Denisova, O.E: Kutafina. Moskva: Izd-vo Mosk. un-ta (in Russian)

9. Kazakov, V.N. \& Malahov, V.P. (2002) Pravosoznanie i pravomernoe povedenie [Legal awareness and lawful behavior]. Moskva: Mos. un-t MVD RF im. V.Ja. Kikotja (in Russian).

10. Rabinovych, P.M. \& Bachynskyi T.V. (2015) Formuvannia osnov pravovoho svitohliadu, pravovoi svidomosti ta pravovoi kultury shkilnoi molodi (teoretyko- y sotsialno-pravove doslidzhennia) [Formation of bases of legal worldview, legal consciousness and legal culture of school youth (theoretical and social-legal research)] U Pratsi Lvivskoi laboratorii prav liudyny i hromadianyna NDI derzh. budivnytstva ta mists. samovr. [Proceedings of the Lviv laboratory of human and civil rights of the Research Institute of State. construction and sites] (s. 35-46.). Lviv: Vyd-vo LOBF "Medytsyna i pravo" (in Ukrainian). 
11. Romanova, A. (2014) Pravomirna povedinka yak umova samostverdzhennia liudyny [Legitimate behavior as a condition of human selfaffirmation]. Yurydychnyi visnyk [Legal Bulletin], (6), 91-95 (in Ukrainian).

12. Holovatyi, S. (2006) Verkhovenstvo prava [The rule of law]. Kn. 3 Ukrainskyi dosvid [Ukrainian experience]. Kyiv: Feniks (in Ukrainian).

13. Shpengler, O. (1998) Zakat Evropy. Ocherki morfologii mirovoj istorii [Sunset of Europe. Essays on the morphology of world history]. T. 2 : Vsemirno-istoricheskie perspektivy [World-historical perspectives]. Translator I. Mahan'kova. Moskva: Mysl' (in Russian).
14. Husariev, S.D. (2005) Yurydychna diialnist: metodolohichni ta teretychni aspekty [Legal activity: methodological and theoretical aspects]. Kyiv: Znannia (in Ukrainian)

15. Konstytutsiia Ukrainy, Zakon Ukrai'ny [Constitution of Ukraine, Law of Ukraine] № 123/96-VR (1996). http://zakon0.rada.gov.ua/laws/show/ $254 \mathrm{k}-\mathrm{vr}$ (in Ukrainian).

\section{LEGITIMACY AS A WORLDVIEW CRITERION FOR ASSESSING CONDUCT AND ACTIVITY}

The author analyzes the genesis of the ideas about the concept of "legitimacy". The focus is on analyzing different conceptual approaches to defining its content, essential characteristics and attributes, as well as the means of practicing legitimate conduct and activity. On the basis of the rule of law and natural legal understanding, the concept of the content of the category "legitimacy" is proposed. Attention is drawn to the contradictory provisions of the Constitution of Ukraine, which become evident in its true understanding.

In particular, the author draws attention to the fact that the genesis of the formation of representations of legitimate conduct leads to the conclusion that initially it was interpreted solely from the standpoint of positivist understanding, which led to the conclusion that the main criterion for its legitimacy is its consistency only with the rules of law. Subsequently, the basic principles of the law began to be recognized as a component of its requirements. And nowadays, the concept according to which the conduct that meets the requirements of not only the provisions of the positive law but also the requirements of other generally recognized social norms that reflect the highest social values is gaining support.

At the same time, while paying tribute to the progressive trends that are followed in these approaches, it should be acknowledged that they continue to be based on a positivist understanding in which the concept of "rule" is equated with the law and its form with its content. With regard to true understanding of the category of "legitimacy", when defining it, it is necessary to proceed from the fact that Ukraine's constitutional recognition of a person, his rights and freedoms as the highest value and the rule of law is the legal basis for the conclusion about the actual transformation of its legal system from traditional positivist legal understanding into natural-legal, according to which the law recognizes not the rules established by the state in the form of law, but human rights and freedoms, the content of which is its powers to own, use and order social values. And with this in mind, it becomes apparent that the concept of "legitimacy" means compliance with the requirements arising from the rights and freedoms of the subjects of the social relations. And since the social norms of conduct are always preceded, this creates the preconditions for a proper assessment of them for compliance with their requirements. As a consequence, in such circumstances, the principle of legality becomes part of the principle of legitimacy, but only if the law is legal.

The main requirements of legitimacy include the rule of law, i.e. the priority of the human rights and freedoms in all the spheres of the public life; their warranty; obligation of their observance by all the participants of legal relations; effective and consistent counteracting; the inevitability of liability for the offense. As for the conditions of the law and order, the principles of the rule of law and, consequently, the legitimacy of conduct and activity, they are the corresponding guarantees, that is, the conditions, means and measures by which they are ensured, in particular: economic, ideological, political, legal, public and international. As for practical ways to ensure the rule of law, law and order and the legitimacy of conduct and activity, they are: persuasion, encouragement, coercive measures, prophylactic activity.

Keywords: law, rule of law, law and order, legitimacy, legality, principles of law, social norms, conduct, activity.

Bulletin of Taras Shevchenko National University of Kyiv.

Legal Studies, 2021; 1 (116): 23-29

Удк: 001:34

DOI: https:doi.org/10.17721/1728-2195/2021/1.116-5
ISSN 1728-2195

(C) Taras Shevchenko National University of Kyiv,

Publishing center "Kyiv University", 2020

Р. Марусенко, канд. юрид. наук, доц. ORCID ID: 0000-0003-3631-9593

Київський національний університет імені Тараса Шевченка, Київ, Україна

\section{ПОКАЗНИКИ ПУБЛІКАЦІЙНОЇ АКТИВНОСТІ ПРАВНИКІВ КРІЗЬ ПРИЗМУ ЗАКОНОДАВЧИХ ВИМОГ}

Критерії оцінки якості наукової роботи вченого в Україні та обов'язки щодо їхнього дотримання в тому вигляді, у якому вони закріплені нормативно, зараз викликають перестороги з боку науковців-правників.

Метою статті є аналіз нормативного регулювання оцінки продуктивності діяльності науковців, які здійснюють дослідження в галузі юридичної науки, окреслення потенційних негативних наслідків реалізації таких норм, а так само аналіз практики інших країн, які вже зіштовхнулись із подібними проблемними питаннями.

За результатами порівняльного аналізу автором наводяться приклади негативних наслідків застосування кількісних показників оцінки продуктивності діяльності науковців і наукових установ в інших країнах, пропонуються можливі шляхи виправлення ситуації в Україні.

Констатується, що встановлення обов'язку публікування результатів наукової роботи у визначеній кількості статей у виданнях, проіндексованих у наукометричних базах Scopus ma Web of science Core Collection, має ряд незативних наслідків для вчених у галузі права. Іноземні видання, проіндексовані у згаданих наукометричних базах, мають обмежений інтерес до правових досліджень національного характеру. Це призводить до ускладнення публікації результатів роботи та появи ряду негативних практик публікації у непрофільних виданнях, здорожчання послуг публікації, появи "хижацьких журналів". Розв'язання проблеми може полягати, зокрема, у відмові від звужувального тлумачення нормативних вимог щодо потреби публікації у виданнях, що індексуються виключно у двох наведених наукометричних базах, і врахування специфріки права як галузі науки, яка має переважно національне значення. Пропонується розширення кола наукометричних баз, а також видань, результати дослідження в яких мають визнаватись як достатня підстава для обліку результатів наукової роботи.

Ключові слова: публікаційна активність, індексація у наукометричних базах, Scopus, наукометричні показники, рейтинг ученого.

ВСтуп. Науковий працівник - це "вчений, який [...] відповідно до трудового договору (контракту) професійно провадить наукову, науково-технічну, науково-організаційну, науково-педагогічну діяльність [...]" [1, с. 1]. На- укова діяльність є творчою активністю й передбачає одержання нових знань, пошук шляхів їхнього застосування тощо. Одержані наукові результати можуть мати різні форми втілення, але серед іншого мають бути 